\title{
THE SUWALKI GAP DILEMMA: A STRATEGIC AND OPERATIONAL ANALYSIS
}

\author{
Leopold Scholtz ${ }^{1}$
}

\begin{abstract}
This article reports on a theoretical analysis about a series of events that will hopefully never take place. Should Russia ever decide to invade the Baltic republics, the obvious invasion route would be from Russian territory into Estonia and Latvia, and perhaps also from the Russian exclave of Kaliningrad into Lithuania. Authoritative war games have found that Russian forces could reach the three Baltic capitals within 36-60 hours. NATO has decided on a counterstrategy, stationing 5000 troops in the three republics and Poland, as well as establishing a rapid reaction force of 13000 troops, capable of being at the front in a week. Nevertheless, this article argues that this is probably insufficient. These troops will have to move through the so-called Suwalki Gap (80 kilometres wide) between Kaliningrad and Belarus, a close Russian ally, which could be closed by a determined Russian push. The article ends with a war scenario, which shows that any clash could rapidly escalate into a general war.
\end{abstract}

Key words: NATO, USSR, Soviet Union, Russia, Kaliningrad, Estonia, Latvia, Lithuania, Baltics, Suwalki, Valery Gerasimov, Vladimir Putin

\section{The problem}

In NATO circles, considerable concern was caused by the aggressive posture taken by Russian President Vladimir Putin, especially after 2014. This followed his - according to international law - illegal invasion, occupation and annexation of the Crimea, and his covert military support for separatist rebels in the eastern Ukraine.

The general expectation was that any future aggression would come either in the Ukraine or the Balkan, or perhaps rather in the areas adjacent to the Baltic Sea. There, it is feared, Putin could try to regain control over the Baltic republics, Estonia, Latvia and Lithuania, territories that used to be part of the old Soviet Union until its demise at the end of $1991 .^{2}$ If - and, of course, that is a big if - that happens, the operational focus would fall on the so-called Suwalki Gap, the some $90 \mathrm{~km}$ wide gap between the Russian exclave of Kaliningrad and the nominally independent ex-Soviet republic of Belarus, a close Russian ally. It is through this gap that NATO would have to rush reinforcements and supplies from Poland to the Baltic republics, and to prevent this, Russia would have to close the gap. As we shall see, because of the specific circumstances regarding this situation, it might quickly spiral out of control once the fuse is lit.

The purpose of this article is, therefore, to present an analysis of the strategic and operational aspects surrounding the possible scenarios regarding the Suwalki Gap in the event of a Russian attempt to retake the Baltic republics. It is a theoretical analysis, which may not - and hopefully never will - play out in real life. 


\section{Vladimir Putin's grand strategy}

When trying to read Vladimir Putin's mind to assess his grand strategy, several factors must be kept in mind.

First is a maxim by the British strategist Sir Basil Liddell Hart, who posed several battlefield guidelines for military commanders several decades ago. One of them was:

Take a line of operation which offers alternative objectives. For you will thus put your opponent on the horns of a dilemma, which goes far to assure the chance of gaining one objective at least - whichever he guards least - and may enable you to gain one after the other. ${ }^{3}$

Liddell Hart was of course writing about the operational level of war, but his words may equally apply to security strategy as well. With this in mind, let us consider the uncertainty of one pair of analysts, Michael A. Hunzeker and Alexander Lanoszka, when analysing Putin's strategy:

Many analysts emphatically insist that Russia is fundamentally revisionist. Others reject this interpretation and maintain precisely the opposite. The first camp believes that Russia harbors irredeemably expansionist ambitions and strives to reassert imperial control over the region. Though Russia is willing to use force to achieve this goal, it is content to use subversion and provocation to shape conditions until the time is right for a fait accompli. The second camp takes a more sympathetic view and portrays Russia as a defensive actor. Fear rather than imperial impulses animates Russian foreign and defence policy. Russia begrudgingly accepts that Estonia, Latvia, Lithuania and Poland are members of NATO. Yet, Russia is justifiably concerned that the United States will do everything in its power to prevent Russia from occupying its rightful place as a great power peer. ${ }^{4}$

A 'one-size-fits-all' military posture towards Russia in the Baltic region may be dangerously inappropriate.

Compounding the problem is that Russia's actions are entirely consistent with both narratives. For example, we can interpret Russian aggression against Ukraine as setting the stage for further expansion. But, such moves can also serve as a way for Russia to signal its red lines so as to deter future NATO expansion. We can even infer Russian intentions from the military capabilities of the country. Although Russia has invested heavily in military modernisation since 2008, its more capable military is just as useful for attacking NATO countries as it is for defending against a NATO attack. ${ }^{5}$

A third concomitant element is the introduction of the concept of 'hybrid warfare' (called "new-generation warfare" by the Russians ${ }^{6}$ ) by the chief of the Russian General Staff, General Valery Gerasimov. In an article in a Russian military journal in February 2013, he wrote of new methods of warfare, which he defined as -

[M]ilitary means of a concealed character, including carrying out actions of informational conflict and the actions of special-operations forces. The open use of 
forces - often under the guise of peacekeeping and crisis regulation - is resorted to only at a certain stage, primarily for the achievement of final success in the conflict.

He went on, referring to "non-standard" applications of force:

The role of mobile, mixed-type groups of forces, acting in a single intelligenceinformation space because of the use of the new possibilities of command-andcontrol systems, has been strengthened. Military actions are becoming more dynamic, active, and fruitful. Tactical and operational pauses that the enemy could exploit are disappearing. New information technologies have enabled significant reductions in the spatial, temporal, and informational gaps between forces and control organs. Frontal engagements of large formations of forces at the strategic and operational level are gradually becoming a thing of the past. Long-distance, contactless actions against the enemy are becoming the main means of achieving combat and operational goals. The defeat of the enemy's objects is conducted throughout the entire depth of his territory. The differences between strategic, operational, and tactical levels, as well as between offensive and defensive operations, are being erased. The application of high-precision weaponry is taking on a mass character. Weapons based on new physical principles and automatized systems are being actively incorporated into military activity. ${ }^{7}$

Asymmetrical actions have come into widespread use, enabling the nullification of an enemy's advantages in armed conflict. Among such actions are the use of special operations forces and internal opposition to create a permanently operating front through the entire territory of the enemy state, as well as informational actions, devices and means that are constantly being perfected. ${ }^{8}$

In his testimony before the Armed Services Committee of the US House of Representatives, Christopher S Chivvis of the RAND Corporation translated the 'Gerasimov doctrine', as practiced, into three objectives:

- $\quad$ capturing territory without resorting to overt or conventional military force;

- $\quad$ creating a pretext for overt, conventional military action; and

- using hybrid measures to influence the politics and politics of countries in the West and elsewhere, which include information operations, using cyberspace, proxies, economic influence, clandestine measures, and political influence. ${ }^{9}$

The Russian take-over of the Crimea, part of Ukraine, may serve as an excellent example. During the night of 27-28 February 2014, heavily armed men, clad in camouflage uniforms without identifying insignia, appeared all over the Crimea. They speedily moved to seal off all Ukrainian military bases and police stations, and occupied all key points in the territory, including broadcasting centres and government buildings. President Putin feigned ignorance, saying that these were "local self-defence forces". At the same time, it later transpired, he visibly placed his nuclear forces in a state of readiness, clearly to warn the Americans not to interfere. In this atmosphere which could hardly be called free - a plebiscite was hurriedly organised, in which an overwhelming majority of those voting indicated their approval of joining Russia. Later, 
a clearly amused Putin admitted on television that the "green men", as they became known, were in fact Russian soldiers acting under his command. ${ }^{10}$ As Ivo Daalder, former US Permanent Representative on the NATO Council, puts it, "this was no traditional military invasion; it was hybrid warfare in which goals were accomplished even before the adversary understood what was going on". ${ }^{11}$

Tactically, it was brilliant. By misleading and surprising the Ukraine and the West, and using overwhelming force for the crucial first 48 hours, Putin ensured that the Crimea was taken without a shot being fired. Likewise, the Russian president clandestinely sent troops to aid the separatist rebels in the eastern Ukraine. Several times, when it seemed as if the Ukrainian army could defeat the rebels, Russian forces stepped in clandestinely and bolstered the separatists. ${ }^{12}$ At the time of writing, the fighting had atrophied into a "frozen conflict".

In 2015, Putin told an American academic, Professor Daniel Treisman (University of California), "the operation to seize the [Crimean] peninsula was 'spontaneous' and 'not at all' planned long in advance". ${ }^{13}$ This fits in with the view that Putin is primarily an excellent tactician with an unerring eye for a gap, rather than a thoughtful strategist with a master plan. At times, he gives the impression that he would like to restore either the entire Soviet Union or, at any rate, the core areas, being the Russian Federation, the Ukraine, Belarus, the Baltic republics and, perhaps, Georgia.

The Russian speakers in the "near abroad", as the independent ex-Soviet republics are known, act as an excuse to interfere in these republics' internal affairs. Putin himself made it crystal clear, "[O]ur country will continue to actively defend the rights of Russians, our compatriots abroad, using the entire range of available means." He added, "I am referring to those people who consider themselves part of the broad Russian community; they may not necessarily be ethnic Russians, but they consider themselves Russian people." 14

Having analysed Putin's public utterances, German political scientist Hannes Adomeit concludes that the old USSR is Putin's "conceptual point of reference", rather than "a precise geographic and geopolitical frame of reference that determine his policies". In 2008, Putin said at an international conference, "[t]he fall of the USSR was a great [sometimes wrongly translated as 'the greatest'] political catastrophe of the $20^{\text {th }}$ century." And in 2011, he said the USSR was simply "Russia under a different name". To him, above all, the value of the USSR was in its status as a superpower, equal to that of the United States. ${ }^{15}$

Putin's tactical brilliance does not mean that he has no grand strategy. Building on Putin's public utterances, Vasily Gatov offers the following reconstruction of Putin's highly nationalist world-view:

Mother Russia is the absolute good. Positive, educated and well-behaved, it fosters the good for all the neighbors and even non-neighbors. Though sometime before Russia was humiliated and surpassed by some obscure forces, it persistently revives itself and 
wants to spread the good it represents. But the entire world is ruled by illiterate others (that are also forces from the past) who persistently conspire to harm to Russia and its legitimate interests. All these others are villains by default; their goal is to dissect and destroy Russia. This is the world of negation and denial; all others are liars and hypocrites. In order to confront this terminal clash of civilizations Russia needs to employ the spiritual power of its history and faith. Russia is wealthy and resourceful and the others envy its richness and potential. In order to pursue their conspiratorial goals, others make propaganda against Russia, send spies and recruit traitors among Russians. Villains also are persistently lecturing an educated and ingenious Russia about what is appropriate and what is not. Cultured and reasonable Russia needs no lecturing from anyone. The behavior of the others shows their hypocrisy and evil goals. ${ }^{16}$

This, it may be reasoned, is a continuation of the idea, popular in the nineteenth century, that Russian culture is exceptional and pure, while that of the West is debased and degenerated. ${ }^{17}$

\section{Putin and the Baltic states}

The geopolitical situation of the Baltic states looks very different, depending on which geographical point of departure - Brussels (being NATO's headquarters) or Moscow - one uses. We shall look at Brussels a little later; let us now concentrate on the view from the Kremlin. Two interrelated factors are relevant.

In the first place, Russia lacks defensible borders. ${ }^{18}$ This facilitated the invasions by Napoleon in 1812 and Hitler in 1941. Therefore, secondly, the real Russian obstacles to invaders are its vast spaces and the intense cold of winter. The distance between Russia's western border and Moscow is so great that even the German mechanised forces, experienced in blitzkrieg, could not reach the capital before the onset of the unbelievably cold winter weather. (Although, it must be said, Hitler's blunder in diverting his forces southwards to Kiev, slowing down the march to Moscow, also played a role. ${ }^{19}$ )

One of the reasons why Stalin placed the greater part of Central Europe under his control in the late forties was that it offered a huge buffer territory. Added to the endless Russian distances, this made any invasion by the West entirely impossible.

However, the dissolution of the Warsaw Pact (NATO's communist counterpart) and of the Soviet Union itself in 1990-1991, changed Russia's geopolitical position dramatically. Instead of the more than $2000 \mathrm{~km}$ from Hannover near the intra-German border to Moscow, which invading NATO forces would have had to transverse, it was reduced to about $800 \mathrm{~km}$ between the border of the nearest NATO member, Latvia, and Moscow. This contributed to a feeling of insecurity in the Kremlin. In the 2015 Russian

National Security Strategy, it is expressly cited as a threat. ${ }^{20}$ As AP Tsygankov puts it:

At the heart of the Kremlin's current view of NATO is the securitized perception of the alliance as reflecting the eternally expansionist drive of Western civilization and its desire to undermine Russia as the alternative other with distinct values and international 
priorities. The primary factors explaining such view of the alliance are the historically built perception of NATO and the alliance's policies following the Cold War. ${ }^{21}$

In an important policy speech in 2007, Putin identified NATO's eastward expansion expressly with - in his eyes - the aim of America to dominate the world. He complained about "[o]ne single center of power. One single center of force. One single center of decision-making. It is a world in which there is one master, one sovereign." 22 The old Russian fear of "encirclement" is once again alive and well in Moscow. ${ }^{23}$

Putin himself expressed the Russian fear graphically in a 2014 speech:

Sometimes I think, maybe it would be better for our bear to sit quiet, rather than to chase piglets in the forest and to eat berries and honey instead. Maybe they will leave [our bear] in peace. They will not. Because they will always try to put him on a chain ... They will rip out its fangs and its claws. Once they've ripped out its claws and fangs, the bear is no longer needed. They will make a stuffed animal out of it ... It is not about Crimea. We are protecting our sovereignty and our right to exist. ${ }^{24}$

As viewed from the Kremlin, the Baltic republics - and, more importantly, their membership of NATO - form a clear threat to Russia's military security. It follows that, even if the Kremlin would not actively try to neutralise them by invasion, not a single tear would be shed in Moscow if that threat collapsed.

The question is, how far would Moscow go? In the short term, it seems, not beyond covert measures to undermine Baltic independence. The presence of sizeable Russianspeaking populations in Estonia (almost 30\% in 201125), Latvia (25\% in $2018^{26}$ ), and Lithuania (almost $6 \%$ in $2011^{27}$ ), may, however, in time provide the Russian government with a potential Trojan horse to stir up trouble. These Russian speakers are concentrated in the border regions. For instance, the population of the Estonian county of Ida-Viru is $73 \%$ Russian-speaking, and the region's largest city, Narva, has $82 \%$ Russian speakers. ${ }^{28}$ This may then be utilised as a pretext for an invasion, much like the role the Sudeten Germans played before the Second World War to make it possible for Adolf Hitler to subjugate Czechoslovakia. In fact, the predominantly Russian-speaking population of the eastern Ukraine was utilised in exactly the same manner. ${ }^{29}$

It is very unlikely that Russia is actively seeking to get embroiled in a war with NATO. Vladimir Putin is not Adolf Hitler. He may rather be seen as a chess master, looking for gaps in his opponents' forces and striking only where there is a reasonable chance of success and where he can neutralise immediate countermeasures through misleading and hybrid warfare.

\section{As Natalya Bugalyova sees it:}

Putin is no mere opportunistic predator. He may not always have a clear plan and acts expediently at times, but he knows what kind of world he wants and, even more so, what kind he does not. He seeks a world without NATO, with the U.S. confined to the Western Hemisphere, with Russia dominant over the former Soviet Union and able 
to do what it likes to its own people without condemnation or oversight, and with the Kremlin enjoying a literal veto at the UN Security Council over actions that any other state wishes to take beyond its borders. ${ }^{30}$

It is, of course, impossible at this conjuncture to predict the future. Based on what is known about Putin's political convictions and his tactical flair, it may be assumed that he will wait until a suitable opportunity arises before striking. And then any actions will start off as plausibly deniable hybrid operations along the lines suggested by General Gerasimov.

Once the Baltics are invaded, their fate is sealed. The Baltic defence forces may slow down the invaders to a limited extent, but will not be able to stop them, let alone repulse them. In a series of war games in 2014 and 2015, the RAND Corporation's conclusions were stark:

As currently postured, NATO cannot successfully defend the territory of its most exposed members. Across multiple games using a wide range of expert participants in and out of uniform playing both sides, the longest it has taken Russian forces to reach the outskirts of the Estonian and/or Latvian capitals of Tallinn and Riga, respectively, is 60 hours. ${ }^{31}$

At any rate, whether Russia is actively considering military action against the Baltics or not, Putin is clearly putting the West "on the horns of a dilemma". ${ }^{32}$ According to the Russian minister of defence, Sergei Shoigu, the Russian military forces in the areas adjacent to Norway, Finland, Poland and the Baltic republics were reinforced with two divisions and three independent brigades, as well as 5000 units of new and overhauled weapon systems and pieces of equipment. More than 350 "military facilities" were made operational. ${ }^{33}$ In addition, the exclave of Kaliningrad (of which more later) has been reinforced with strong conventional land and naval forces and strategic missiles. ${ }^{34}$ Several large-scale exercises in Western Russia and the Baltic Sea have honed the Russian military, should Putin decide to take the plunge. ${ }^{35}$

At the same time, according to a study by the Institute for the Study of War, the Russian defence force has stationed three mechanised divisions along the Ukrainian border. ${ }^{36}$ This means that the Russians are well placed to strike wherever they want, while NATO is kept guessing as to the Kremlin's intentions.

\section{The view from Brussels}

Obviously, the view from Brussels - and Riga, Talinn and Vilnius - is very different to that from Moscow. From NATO's point of view, Russia is seen as a threat. The threat manifested itself for the first time when Russian forces invaded the (again, Russianspeaking) northern Georgian territory of Abkhazia in 2008 and converted it into a selfruling area under Russian control. ${ }^{37}$ 
In 2013, the RAND Corporation, funded by the US government, ${ }^{38}$ analysed the Baltic states' defence against a possible Russian invasion. The conclusion, as stated previously, was that "NATO cannot successfully defend the territory of its most exposed members", especially that of the Baltics. At the most, it would take between 36 and 60 hours for the Russian forces to reach the Estonian and Latvian capitals, Tallinn and Riga, on the Baltic coast.

Such a rapid defeat would leave NATO with a limited number of options, all bad: a bloody counteroffensive, fraught with escalatory risk, to liberate the Baltics; to escalate itself, as it threatened to do to avert defeat during the Cold War; or to concede at least temporary defeat, with uncertain but predictably disastrous consequences for the Alliance and, not incidentally, the people of the Baltics. ${ }^{39}$

What would NATO's response be to such an invasion? There is some difficulty to interpret President Donald Trump's position. At various times, he has said that the United States would not automatically come to the help of small states threatened by Russia. ${ }^{40}$ This in spite of Article 5 of the NATO Charter, which expressly states, "[t] he Parties agree that an armed attack against one or more of them in Europe or North America shall be considered an attack against all of them", and that they will come to each other's aid if such an attack occurs. ${ }^{41}$

In 2017, Time magazine reported that the Trump administration had an internal debate:

[O]ver whether the U.S. should resist Putin in his new campaign or cede to Russia a sphere of influence in Eastern Europe. In return for the latter, the theory goes, Russia would join the U.S. in an alliance against ISIS [Islamic State of Iraq and Syria], work to reduce nuclear-weapon stockpiles and help to constrain China. ${ }^{42}$

Judging by what subsequently happened, this approach seems to have been abandoned, but a question mark continues to hang over the Trump government's unconditional commitment to NATO.

Nevertheless, NATO - with the apparent grudging support of Trump - has taken several measures to bolster the Baltics' defence against Russia. While the Baltics themselves have strengthened their modest military capability to 57000 full-time soldiers and reservists (including the training of guerrilla forces to harass the Russians after an invasion ${ }^{43}$ ), NATO decided at its Wales summit in 2014 to establish a "Very High Readiness Force" of 5000 men in the Baltics. This force - three infantry battalions, one in each of the republics and a fourth in Poland - would consist of contingents supplied by several member states and would be rotated every few months. They would serve as a kind of trip wire to slow down invasion forces and alert the rest of NATO. Then the so-called Nato Spearhead Force (13 000 troops) would be mobilised and made ready for deployment within 48 hours. It could be at the front within a week. The task of this force would then be to win time for the rest of NATO to be readied for a bigger war. Finally, they would be followed by a Very High Readiness Joint Task Force (27 000 
troops), but the presence of these troops on the battlefield would not be felt before 30 days. ${ }^{44}$ This, too, has been exercised by NATO in large-scale manoeuvres. ${ }^{45}$ (In addition, Poland is planning to augment its present three army divisions with a fourth. The Polish government is also pressuring America to station a US division permanently on its territory. ${ }^{46}$ ) This is where the so-called Suwalki Gap comes into play.

\section{The Suwalki Gap}

The Suwalki Gap takes its name from a Polish town in the far northeast of the country, near the Lithuanian border. In order to grasp its significance, we will have to look at the geography of the region first.

Squeezed in between Lithuania and Poland, there is a Russian exclave, approximately 140 square kilometres in size, known as the Oblast (region) Kaliningrad, named after the capital city, Kaliningrad. The city was named after Mikhail Ivanovich Kalinin, the first head of state of the Soviet Union from 1919 to 1946. Until 1945, however, the city was the capital of East Prussia and known as Königsberg. East Prussia was a German exclave, which was divided into two sections in 1945. The southwestern half was given to Poland (then a Soviet satellite state), and the northeastern half to the Soviet Union as the Oblast Kaliningrad. The German inhabitants fled or were forcibly expelled.

The region was placed under the administrative control of the Russian Federation, the dominant constituent state of the Soviet Union. While the USSR existed, this posed no problem. But when the USSR fell apart at the end of 1991 into its 15 constituent republics, Kaliningrad found itself cut off from Russia, separated by the newly independent Belarus.

The existence of the region as an exclave poses strategic problems for Russia, but also has some advantages. The main problem is that its exposed position makes it vulnerable to attack and difficult to defend, unless very strong forces are stationed there. On the other hand, Kaliningrad turned out to be an excellent forward position, able to threaten both the Baltic states and Poland. And, being the base of medium-range nuclear missiles, it also threatens the Central European capitals of Warsaw, Budapest, Prague and Bratislava - and even Vienna and Berlin.

Should President Putin ever decide to take the Baltics, geography dictates an invasion from the Russian territory immediately east of Estonia and Latvia, as well as from Kaliningrad. This means that the Baltic republics may be invaded simultaneously from the east and the southwest, making any defence difficult.

If NATO theory is brought into practice, the alliance will then mobilise its Spearhead Force. While the Very High Readiness Force, together with the Baltic militaries, tries to slow down the Russian advance, the Spearhead Force will assemble along the border between Lithuania and Poland and try to hit the Russian invaders in their southern flank.

This border, about 90 kilometres long, is called the Suwalki Gap. But hitting the Russian invaders will not be as easy as it sounds. On the western side, the border ends 
at the Oblast Kaliningrad; on the eastern side, at the Belorussian border. Belorussia is an independent ex-Soviet state, but normally stays close to Russia in its foreign policy. It is quite conceivable that the country may allow Russia to utilise its territory to help stage an invasion of Lithuania and to close off the Suwalki Gap. ${ }^{47}$ At the same time, the Kaliningrad region at the other end of the Gap is well placed to plug the hole as well.

Any NATO force trying to get through to Lithuania and the other Baltic countries, will therefore have to fight their way through a Russian army which, in the short term, will be considerably stronger. Under no circumstances should the difficulty be underestimated.

As Professor Mark Galeotti of the Royal United Services Institute points out in a thoughtful piece,

[W] hile in the longer term NATO could use its greater aggregate troop numbers and economic muscle to grind Russia down, Moscow's forces are in a much stronger position to dominate in the crucial first couple of weeks of any European war. The Russian calculus is that there may not be a longer term, especially if it was able to threaten nuclear strikes or similarly-disabling precision conventional ones to bring a conflict to an early end. ${ }^{48}$

In other words, although Russia's relatively weak economy makes the country vulnerable in a somewhat longer war, its considerably stronger forces at the flashpoint give them an advantage not to be trifled with, especially if they succeed in achieving tactical and operational surprise, as they did in the Crimea.

Traditionally, NATO's operational approach has been to cede territory for time. That is, to fall back before an overwhelming Soviet offensive and to slow it down, to use that time to gather its own forces, and then to unleash a counteroffensive. However, that situation has changed - at any rate, as far as the Baltic states are concerned. Here, defence in depth is simply impossible for NATO, due to the small size of the states.

A study co-authored by a previous commanding general of US forces in Europe, Lieutenant General Ben Hodges, makes it clear exactly how important the Suwalki Gap is. Three features are identified:

- $\quad$ the Suwalki Gap separates the Russian motherland from Oblast Kaliningrad and its naval bases;

- $\quad$ cutting off the corridor could strangle the three Baltic states and prevent NATO aid from getting through; and

- closing the corridor "would provide Moscow with a contiguous military front between the Baltic Sea and Ukraine, consolidate its political stranglehold over Belarus, and more directly threaten Poland's sovereignty and territorial integrity". 49

Even if Belarus does not allow the Russians the use of its territory, the Russian possession of Kaliningrad is a very strong tactical and operational advantage. While 
the author of this article does not have the privilege of being privy to secret NATO war plans, logic dictates that the alliance will have to do something about the exclave very soon after hostilities break out. Nikolai Sokov, a Russian-American academic, refers to "the artillery and short-range missiles" stationed in Kaliningrad. He paints an interesting picture of the difficulties NATO forces would encounter in the Suwalki region:

Terrain is difficult and there are only two roads [as well as one railway line - LS] that allow fast reinforcement. The bottom line - Russia does not have to send tanks, as everyone fears, to prevent NATO reinforcements: it can use artillery or other strike assets to destroy the roads and keep the them closed for a fairly extended period of time. If the RAND Corporation estimate (thirty-six to sixty hours) is to be believed, then these reinforcements should arrive hours sooner, perhaps in twenty-four hours or so. If one imagines a more efficient Russian offensive, then they should be in place twelve to eighteen hours after commencement of hostilities. ${ }^{50}$

Besides, many railways, bridges and roads leading up to the Gap through Germany and Poland, as well as the ports in the vicinity, are - at the time of writing, at any rate not able to handle the very heavy traffic and heavy equipment, such as tanks and artillery pieces that will have to traverse them on the way to the Gap. ${ }^{51}$ At least one White House war game exercise found that these logistical problems resulted in a NATO loss. ${ }^{52}$

Moreover, a report co-authored by General Hodges, makes it clear that the vicinity is not very conducive to manoeuvre warfare:

One of the most significant takeaways: large parts of the Suwałki Corridor can be a nightmare for maneuver. The region's confined rolling fields are disrupted by chain lakes, rivers, streams, thick stands of forest, and muddy soil during rainy seasons, favoring the defender. Only two narrow roads physically connect the Polish-Lithuanian border - making for a tight and predictable funnel through which to move brigade-sized or larger formations. ${ }^{53}$

Of course, the NATO Response Force is mechanised. The poor physical infrastructure of the region therefore does not have to render its march up to and into the Suwalki Gap impossibly difficult. It is logical to assume that this force would carry enough supplies in its B echelon to sustain the force for at least a few days. But after that, the rear echelon will have to resupply the combat force. If too much reliance is put on wheeled vehicles, things may turn nasty. (Take into account that NATO doctrine calls for the maximum utilisation of civilian equipment, which means soft-skinned wheeled transportation, ${ }^{54}$ which may struggle getting supplies to the Suwalki Gap region and into Lithuania.)

\section{The Kaliningrad problem}

We have seen how the Oblast Kaliningrad, being cut off from the Russian motherland, is a relatively exposed and vulnerable territory but, at the same time, a valuable forward asset. Its main value lies in the possibility of augmenting a Russian invasion into the Baltics from the east with a simultaneous advance from the southwest, of helping to close down the Suwalki Gap, and blackmailing the eastern NATO members with nuclear missiles. ${ }^{55}$ 
Any NATO general pondering how to respond to a Russian invasion of the Baltic states will necessarily have to focus on the role of Kaliningrad as well. How to neutralise that threat?

If the planned counteroffensive by the NATO Response Force to reinforce the Baltic defenders is to happen in all seriousness (as compared to an empty symbolic gesture), the threat from Kaliningrad will have to be neutralised at all costs and very quickly. Therefore, according to Sokov, a "massive increase of NATO presence in the vicinity of the Suwalki Gap should remain part of the menu of options". ${ }^{56}$

Another obvious course of action is to take out the Russian military in the Kaliningrad region almost from the first hour of fighting. This may entail a ground offensive to occupy the region and destroy all Russian military equipment there. However, that would be very risky in view of the considerable military build-up in the exclave and the danger of escalation, perhaps even to nuclear level. The alternative is an overwhelming air and missile bombardment to paralyse the Russian forces in the vicinity right from the beginning. In the light of the incomparably smaller risk to NATO, it stands to reason that this option would be favoured by the military and political structures of the alliance. That would, however, only be possible if the NATO forces in Poland and Lithuania are considerably strengthened, as the present forces are clearly not strong enough for the task. $^{57}$

In the last quarter of 2018, several Western news outlets carried reports that US satellite images have picked up a considerable reinforcement of Russian military numbers and modernisation of equipment and missile facilities, including mediumrange Iskander nuclear missiles, in the Kaliningrad region. One US defence official is reported to have called the reinforcement "the biggest move we've seen" in terms of the Russian militarisation of the Baltics. ${ }^{58}$ According to another unconfirmed report, the number of Russian tanks in Kaliningrad was increased from 40 to 100 at the beginning of 2019. ${ }^{59}$ The region also houses the headquarters of the Russian Baltic Fleet. An analysis by the Institute for the Study of War (ISW) makes it clear that an army corps (the 11th) was stationed in Kaliningrad under the command of Major-General Yuri Yarovitski. The corps consisted of two army motorised infantry brigades, a naval infantry brigade, an artillery brigade, a missile brigade, and an anti-aircraft missile brigade. ${ }^{60}$ It is not known how many men and women in uniform there might have been, but it might well be in the range of 10 000-15 000. And this does not even include the warships and military aircraft stationed there.

In any language, this amounts to a very tough nut to crack.

\section{A war scenario}

Let us now imagine a - theoretical - war scenario between Russia and NATO in the Baltic region. ${ }^{61}$ Given the Russian doctrinal propensity for avoiding conventional clashes in favour of hybrid warfare, it is logical to assume that Russia will not attempt a full-scale invasion after a period of increasing tension and build-up of its forces along the border. After all, that would give NATO ample warning to start countermeasures. 
Instead, one may assume a lightning strike without warning. Combined with a smoke screen, figuratively speaking, to place NATO "on the horns of a dilemma" 62 and mislead the West, this would slow down any NATO response considerably. It stands to reason that the invaders would strive to stay below the Article 5 threshold as long as possible.

In an ideal situation - from Moscow's perspective - NATO could even be persuaded not to intervene at all. This was what happened in the Crimea and the eastern Ukraine bearing in mind that NATO's Article 5 did not apply to those regions. One may assume that Russia will see to it that a plausible excuse for its own military movements is given, one that effectively paints NATO as the aggressor instead of Russia.

In the light of the Crimea intervention, one may imagine heavily armed "green men" (as they were then referred to) in unmarked uniforms popping up in the eastern regions of Estonia and Latvia adjacent to Russia, and in the western part of Lithuania next to Kaliningrad. The Kremlin says that the Baltic states are conducting operations against the Russian-speaking areas close to the Russian border. Confusion reigns in NATO capitals as intelligence services and politicians scramble to make sense of what is happening.

The "green men" are rapidly reinforced, and within 24 - perhaps 36 - hours, it is clear that they are in fact Russian troops - by which time they are well on their way to the Baltic coast and the capital cities of the three republics. The Baltic military and the NATO troops in these countries fight back valiantly and succeed in slowing down the Russian advance, but not in stopping it. At the same time, asymmetric tactics, information and cyber warfare, are used to disrupt infrastructure, as well as to increase general confusion and - most importantly - erode the resolve of those in command of the defenders. (These, it may be prudent to remind readers, were the exact results of the enormous speed of Nazi Germany's blitzkrieg tactics during the first years of the Second World War. ${ }^{63}$ )

In the meantime, NATO mobilises its Spearhead Force and rushes it to the border between Poland and Lithuania. In addition, Poland fears that the Russians will not stop at the border and orders a general mobilisation. The NATO troops, in conjunction with the Polish, move up to the Suwalki Gap. They are, however, slowed down by Russian air attacks, causing considerable casualties. Other reinforcements are brought in by sea, but are subjected to severe Russian air and naval attacks originating from Kaliningrad and the St. Petersburg area.

NATO bombers and warships unleash a concerted bombardment on Russian troops and military installations in the Oblast Kaliningrad, dealing the Russians a very heavy blow there. Warships clash in the Baltic Sea, but the NATO ships, being more modern and better equipped, dish out more punishment than they receive.

It is here that things may start to become very dangerous very fast. If the Russians fear that NATO may invade and occupy Kaliningrad, they may decide to escalate the war, which up to that point has been confined to the Baltic area. According to the usually very well-informed US investigative journalist Bob Woodward, Russia "had privately 
warned [Defence Secretary General Jim] Mattis that if there was a war in the Baltics, Russia would not hesitate to use tactical nuclear weapons against NATO". ${ }^{64}$ But even if that does not happen, they may very well widen the operational area by stirring trouble or even invading the Ukraine and the Balkan NATO members. If that threshold is passed, what started as a regional clash, may degenerate into a Third World War.

To prevent this scenario, a RAND Corporation study found a force of about seven mechanised brigades, including three heavy armoured brigades, adequately supported in the air and on the sea, the minimum required to defeat the Russians. ${ }^{65}$ However, even the Spearhead Force does not provide this minimum of firepower. And that assumes that the forces reach the operational area in time to prevent the Russians from confronting NATO with a fait accompli, the effective occupation of all three states even before NATO could intervene. It is known that Russian military doctrine heavily favours a lightning offensive. ${ }^{66}$

As things stand at the time of writing, it does not seem as if NATO would be able to prevent Russia from occupying the Baltic states. Possession is nine-tenths of the law, the saying goes. As with the Crimea, if the Russians have possession of the Baltics, it is extremely unlikely that they will willingly relinquish it. They will most probably sit tight and wait for the storm to subside.

NATO, therefore, has two options and one hope. The first option is to continue pretending that its present countermeasures are adequate to stop and even roll back a Russian invasion, and to do nothing further. The second is to increase its defence spending considerably (politically a highly unpopular choice) and to establish ready forces strong enough to deal with Russian aggression - and to be on station in time to do it. In the absence of this, one hope remains: that President Putin will not risk a full-blown war with NATO, even one he can win in the short term. If so, it will not be because NATO's present countermeasures have intimidated him, but rather because the vulnerable Russian economy cannot sustain a war with NATO for any considerable period. Nevertheless, a seasoned observer, such as Ambassador Wolfgang Ischinger, chairman of the Munich Security Conference, writes about "our sleepwalking into a serious confrontation over the Baltics". ${ }^{67}$ This risk is all the greater because the NATO and Russian armed forces are - according to a news report - "barely on speaking terms". The former US Supreme Commander of NATO forces, General Curtis Scaparotti, complained that the communication between the two sides has mostly broken down. ${ }^{68}$

As things are now, the Russian military is not suitably stationed for an invasion of the Baltics. ${ }^{69}$ But will this last? All in all, nobody can relax. 


\section{ENDNOTES}

${ }^{1}$ Dr Leopold Scholtz is a retired political commentator, writing for several news media. $\mathrm{He}$ is also a military historian with many academic publications on his CV, and the writer of The SADF in the Border War 1966-1989 (Cape Town: Tafelberg, 2013) as well as The Battle of Cuito Cuanavale (Solihull: Helion, 2016) and Ratels on the Lomba: The story of Charlie Squadron (Johannesburg: Jonathan Ball, 2017). He is a research fellow at North-West University's Research Focus Area Social Transformation (Potchefstroom campus). He retired as a captain in the Reserve Force of the South African Army.

${ }^{2} C f$. for instance L Brown. "Putin's dry run for invading Europe". Daily Mail. 21 December 2017.

${ }^{3}$ BH Liddell Hart. Strategy. New York, NY: Praeger, 1954, 348.

${ }^{4}$ MA Hunzeker \& A Lanoszka. "Threading the needle through the Suwalki Gap". EastWest Institute. 26 March 2019. $<$ https://www.eastwest.ngo/idea/ threading-needle-through-suwa\%C5\%82ki-gap $>$ Accessed on 2 May 2019.

${ }^{5}$ Ibid.

${ }^{6} \mathrm{U}$ Kühn. Preventing escalation in the Baltics: A NATO playbook. Washington, DC: Carnegie Endowment for International Peace, 2018, 15. [The part in yellow was included in your other two references to the source. Check.]

${ }^{7}$ Ibid.

${ }^{8}$ V Gerasimov. "Russian military doctrine by General Valery Gerasimov". R Coalson, trans.Year. $<$ https://www.facebook.com/notes/robert-coalson/russianmilitary-doctrine-article-by-general-valery-gerasimov/10152184862563597/>

Accessed on 4 May 2019. In March 2019 he repeated these thoughts in a speech in Moscow. $C f$. AE Kramer. "Russian General pitches 'information' operations as a form of war". New York Times. 2 March 2019.

${ }^{9}$ CS Chivvis. "Understanding Russian 'hybrid warfare' and what can be done about it". Testimony. 22 March 2017. <https://www.rand.org/content/dam/rand/pubs/ testimonies/CT400/CT468/RAND_CT468.pdf > Accessed on 4 May 2019.

${ }^{10} \mathrm{Cf}$. M Murphy \& G Schaub Jr. “'Sea of peace' or sea of war: Russian maritime hybrid warfare in the Baltic Sea". Naval War College Review 71/2. Spring 2018. 1-2; M Kofman et al. Lessons from Russia's operations in Crimea and Eastern Ukraine. Santa Monica, CA: RAND Corporation, 2017, 5-25. [List all authors]

${ }^{11}$ I Daalder. "Responding to Russia's resurgence". Foreign Affairs November/December 2017. 33.

${ }^{12}$ A Scrinic. "Humanitarian aid and political aims in Eastern Ukraine: Russian involvement and European response". Eastern Journal of European Studies 5/2, December 2014. 77-89; E Pond. "Putin's long war". New Statesman. 27 February - 5 March 2015. 27-30.

${ }^{13}$ D Treisman. "Why Putin took Crimea". Foreign Affairs 1. 2016. 47.

${ }^{14}$ Daalder op. cit., p. 33. 
${ }^{15}$ H Adomeit. "Putin's 'Greater Russia': Misunderstanding or mission?” Raam op Rusland. 27 February 2019. < https://www.raamoprusland.nl/dossiers/roesskimir/878-putin-s-greater-russia-misunderstanding-or-mission $>$ Accessed on 8 May 2019.

${ }^{16}$ VV Gatov. “Contagious tales of Russian origin and Putin's evolution”. Society 53/2016. 620, 621

${ }^{17}$ For an intensive analysis of the 19th-century Russian soul and culture, $c f$. O Figes. Natasha's dance: A cultural history of Russia. London: Penguin, 2003.

${ }^{18} \mathrm{R}$ Kaplan. The revenge of geography: What the map tells us about conflicts and the battle against fate. New York, NY: Random House, 2012, 155.

${ }^{19}$ BH Liddell Hart. History of the Second World War. London: Cassell, 1970, 166-167.

${ }^{20} \mathrm{~J}$ Kyle. Contextualizing Russia and the Baltic States. Place: Foreign Policy Research Institute, 2019, 107.

${ }^{21}$ AP Tsygankov. "The sources of Russia's fear of NATO". Communist and PostCommunist Studies 51. 2018. 103.

${ }^{22}$ Cited by Daalder op. cit., p. 32.

${ }^{23} \mathrm{R}$ Sokolsky. The new Russian-NATO military balance: Implications for European security. Washington, DC: Carnegie Endowment for International Peace, 2017, 5.

${ }^{24}$ Cited in N Bugalyova. How we got here with Russia: The Kremlin's world view. Washington, DC: Institute for the Study of War, 2019, 21.

${ }^{25}$ Wikipedia. "Demographics of Estonia". 2019. $<$ https://en.wikipedia.org/wiki Demographics of Estonia\#Languages $>$ Accessed on 8 May 2019.

${ }^{26}$ Wikipedia. "Demographics of Latvia". 2019. $<$ https://en.wikipedia.org/wiki/ Demographics of Latvia\#Ethnic groups $>$ Accessed on 8 May 2019.

${ }^{27}$ Wikipedia. "Demographics of Lithuania". 2019. < $\underline{\text { https://en.wikipedia.org/wiki/ }}$ Demographics_of_Lithuania\#After_World_War_II $>$ Accessed on 8 May 2019.

${ }^{28}$ Kyle op. cit., p. 108.

${ }^{29}$ D Patrikarakos. "In eastern Ukraine, the protesters wait for Russia". New Statesman. 11-17 April 2014. 13-15. For an analysis about the way Russia has already used Estonia's Russian speakers to stir up trouble, see L Robinson et al. Modern political warfare: Current practices and possible responses. Washington, DC: RAND Corporation, 2018, 85-102.

${ }^{30}$ Bugalyova op. cit., p. 25.

${ }^{31}$ DA Shlapak \& MW Johnson. Reinforcing deterrence in NATO's eastern flank: Wargaming the defense of the Baltics. Washington, DC: RAND Corporation, 2016, 1 .

${ }^{32}$ BH Liddell Hart. Strategy. New York, NY: Praeger, 1954, 348.

${ }^{33}$ J Adamowski. "Amid Russian military buildup, Poland reacts". Defense News. 27 August 2018.

${ }^{34} \mathrm{C}$ Woody. "Russia appears to be building up its military bases near a weak point in the NATO alliance”. Business Insider. 11 July 2018. < https://www. businessinsider.nl/russia-building-up-military-base-in-kaliningrad-nearsuwalki-gap-2018-7/?international=true\&r=US $>$ Accessed on 1 May 2019.

${ }^{35}$ A Higgins. "Russia's war games with fake enemies cause real alarm". New York Times. 13 September 2017. 
${ }^{36} \mathrm{C}$ Harris \& FW Kagan. Russia's military posture: Ground Forces order of battle.

Washington, DC: Institute for the Study of War, 2018, 1.

${ }^{37} \mathrm{~S}$ Pruitt. "How a five-day war with Georgia allowed Russia to reassert its military might”. History. Day month year. $<$ https://www.history.com/news/russiageorgia-war-military-nato $>$ Accessed on 11 May 2019.

${ }^{38} \mathrm{Cf}$. https://mediabiasfactcheck.com/rand-corporation/ Accessed on 13 May 2019. [Give the full details of the source]

${ }^{39}$ Shlapak \& Johnson op. cit., p. 1.

${ }^{40} \mathrm{Cf}$. M Fisher. "Donald Trump's ambivalence on the Baltics is more important than it seems". New York Times. 22 July 2017; J Wagner. "Trump says defending tiny NATO ally Montenegro could lead to World War III". Washington Post. 18 July 2018.

${ }^{41}$ North Atlantic Treaty Organization. "The North Atlantic Treaty”. 2019.

$<$ https://www.nato.int/cps/en/natolive/official texts_17120.htm $>$ Accessed on 13 May 2019.

42 "The trouble with Russia". Time Magazine. 27 February - 6 March 2017. [So no author?]

${ }^{43}$ Kyle op. cit., p. 109; S Flanagan et al. Deterring Russian aggression in the Baltic States through resilience and resistance. Santa Monica, CA: RAND Corporation, 2019.

${ }^{44}$ J Ringsmose \& S Rynning. "The NATO Response Force: A qualified failure no more?" Contemporary Security Policy 38/3. 2017. 447.

${ }^{45}$ H Cooper. "“Cold War' takes new meaning for U.S. marines at a NATO exercise”. New York Times. 31 October 2018.

${ }^{46}$ Adamowski op. cit.

${ }^{47}$ M Clark \& N Bugayova. "Russia in review, May 9-13, 2019". Institute of the Study of War. $<$ http://iswresearch.blogspot.com/2019/05/russia-in-reviewmay-9-13-2019.html $>$ Accessed on 15 May 2019; D Axe. "Is Russia trying to take over Belarus?" The National Interest. 14 May $2019<$ URL $>$ Accessed on 15 May 2019.

${ }^{48}$ M Galeotti. "Russia and NATO both think that time is on their side". Raam op Rusland. Day month year. <https://www.raamoprusland.nl/dossiers/militairbeleid/1267-russia-and-nato-both-think-time-is-on-their-side $>$ Accessed on 9 May 2019.

${ }^{49}$ B Hodges, J Bugajski \& PB Doran. Securing the Suwalki Corridor: Strategy, statecraft, deterrence and defense. Washington, DC: Center for European Policy Analysis, year, 22.

${ }^{50}$ N Sokov. "How NATO could solve the Suwalki Gap dilemma". The National Interest. 1 May 2019. < https://nationalinterest.org/feature/how-nato-could-solvesuwalki-gap-challenge-55347> Accessed 2 May 2019.

${ }^{51}$ Hodges et al. op. cit., p. 8.

${ }^{52} \mathrm{M}$ Birnbaum. "If they needed to fend off war with Russia, U.S. military leaders worry they might not get there in time". Washington Post. 24 June 2018.

${ }^{53}$ Hodges et al. op. cit., p. 18.

${ }^{54}$ North Atlantic Treaty Organization. "NATO logistics handbook". October 2017. $<$ https://www.nato.int/docu/logi-en/1997/lo-1403.htm> Accessed 15 May 2019, Chapter 14. 
${ }^{55}$ Sokov op. cit.

${ }^{56}$ Ibid.

${ }^{57}$ C Gao. "NATO's worst nightmare: Russia's Kaliningrad is armed to the teeth". The National Interest. 25 May 2018. < https://nationalinterest.org/blog/the-buzz/ natos-worst-nightmare-russias-kaliningrad-armed-the-teeth-25958 $>$ Accessed 1 May 2019.

${ }^{58} \mathrm{O}$ Lieberman, F Pleitgen \& V Cotovio. "New satellite images suggest military buildup in Russia’s strategic Baltic enclave". CNN. 17 October 2018. $<\underline{\text { https://edition. }}$ cnn.com/2018/10/17/europe/russia-kaliningrad-military-buildup-intl/index. html $>$ Accessed 15 May 2019.

${ }^{59}$ AP Nielsen. "Russia increases number of tanks in Kaliningrad". Romeo Squared. 28 January 2019. <https://romeosquared.eu/2019/01/28/russia-increases-numberof-tanks-in-kaliningrad/ $>$ Accessed 15 May 2019. Nielsen is a military analyst at the Center for Maritime Operations at the Royal Danish Defence College.

${ }^{60}$ Harris \& Kagan op. cit., p. 19.

${ }^{61}$ Several such scenarios have been written. $C f$. AP Nielsen: "How would a war between Russia and the West play out?" Romeo Squared. 1 January 2018. $<\underline{\text { https:// }}$ romeosquared.eu/2018/01/01/the-military-scenario/ $>$ Accessed on 28 January 2019; K Osborn. "NATO vs. Russia in a war for the Baltic states: Who wins?" The National Interest. 8 November 2018. <https://nationalinterest.org/blog/ buzz/nato-vs-russia-war-baltic-states-who-wins-35532> Accessed on 28 January 2019; Kühn op. cit.; D Barrie et al. Defending Europe: Scenariobased capability requirements for NATO's European members. London: International Institute for Strategic Studies, April 2019.

${ }^{62}$ BH Liddell Hart. Strategy. New York, NY: Praeger, 1954, 348.

${ }^{63}$ Cf. JFC Fuller. The conduct of war 1789-1961: A study of the impact of the French, Industrial and Russian revolutions on war and its conduct. London: Eyre \& Spottiswoode, 1961, 267-257.

${ }^{64}$ B Woodward. Fear. Trump in the White House. London, Simon \& Schuster, 2018, 132.

${ }^{65}$ Shlapak \& Johnson op. cit., p. 8.

${ }^{66}$ Kyle op. cit., p. 113.

${ }^{67}$ Cited in Kühn op. cit., p. i.

${ }^{68} \mathrm{R}$ Burns. US-Russia chill stirs worry about stumbling into conflict. Place: Associated Press, 14 April 2019.

${ }^{69}$ Harris \& Kagan op. cit., p. 14. 